\title{
A comparative study of simulation results between PHERB, ADVISOR and AUTONOMIE models
}

\author{
J. S. Norbakyah, A. R. Salisa \\ Faculty of Ocean Engineering Technology and Informatics, Universiti Malaysia Terengganu, Terengganu, Malaysia \\ Renewable Energy and Power Research Interest Group (REPRIG), Universiti Malaysia Terengganu, Terengganu, \\ Malaysia \\ Energy Storage Research Group (ESRG), Universiti Malaysia Terengganu, Terengganu, Malaysia
}

\begin{tabular}{|c|c|}
\hline Article Info & ABSTRACT \\
\hline Article history: & In this research, a new model development and innovation of conventional \\
\hline Received Jun 26, 2020 & boat named plug-in hybrid electric recreational boat (PHERB) was \\
\hline Revised Feb 17, 2021 & comparison simulation results of PHERB with advanced vehicle simulator \\
\hline Accepted Mar 13, 2021 & $\begin{array}{l}\text { (ADVISOR) and an automotive simulation and analysis tool } \\
\text { (AUTONOMIE) models in terms of electric machine, energy system storage, }\end{array}$ \\
\hline Keywords: & $\begin{array}{l}\text { propeller and boat model. The model of the PHERB is consequent and } \\
\text { applied mathematically in the MATLAB/Simulink environment to study its }\end{array}$ \\
\hline Electric vehicles & functioning performance. Besides that, fuel economy and emissions of \\
\hline Emissions & $\begin{array}{l}\text { PHERB, ADVISOR and AUTONOMIE model are equated and the pros and } \\
\text { cons were discussed in this paper based on simulation result. }\end{array}$ \\
\hline Energy management strategy & \\
\hline
\end{tabular}

This is an open access article under the CC BY-SA license.

\begin{abstract} boat named plug-in hybrid electric recreational boat (PHERB) was (ADVISOR) and an automotive simulation and analysis tool (AUTONOMIE) models in terms of electric machine, energy system storage, the PHERB is consequent and functioning performance. Besides that, fuel economy and emissions of cons were discussed in this paper based on simulation result.
\end{abstract}

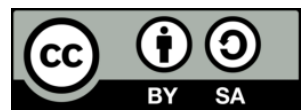

\section{Corresponding Author:}

\section{A.R. Salisa}

Faculty of Ocean Engineering Technology and Informatics

Universiti Malaysia Terengganu

21030 Kuala Nerus, Terengganu, Malaysia

Email: salisa@umt.edu.my

\section{INTRODUCTION}

Malaysia is a promptly emerging country in Southeast Asia that aims to achieve high-income country status by 2050; its economic growth is highly dependent on fuel consumption. The conventional boat (CB) is used only internal combustion engine (ICE) to power the boat. Figure 1 Figure 2 and Figure 3 display the powertrain diagrams block for a $\mathrm{CB}$, plug-in hybrid electric boat (PHEB) and the proposed plug-in hybrid electric recreational boat (PHERB). These block diagrams consist of ICE, electric machine (EM), and energy system storage (ESS) [1], [2]. The PHEB has motor and generator in EM, and an ESS without ultracapacitor (UC) [3]-[8]. Along these lines, PHERB was proposed in this work for cost sparing which one EM was work as either an engine or generator at any given moment. In ESS, there is battery and UC bank for quick charging and releasing amid the regenerative braking and quick increasing speed. The ICE is required when the condition of charge (SOC) of the ESS is low, then ICE only mode is activated. The ICE in PHERB can drive the boat while charging the ESS until the ESS SOC achieves an abnormal state and the EM will assume control to move the boat. Energy management strategy (EMS) for the PHERB is expected to spare the weight, space and cost in addition to enhance the fuel economy and emission.

Modeling and simulation are the important part in development model [9]-[12]. Currently, researchers focus on understanding the progressing system of the hybrid vehicles by developing the simulators [13], [14]. The results can be used to optimize the design of hybrid vehicles before prototype 
structure begins. Besides that, power flow management, optimization of the fuel economy and reducing the emissions are part of the current research [15]-[18]. Several computer programs have been developed to describe the operation of hybrid electric powertrains [19] including advanced vehicle simulator (ADVISOR) and an automotive simulation and analysis tool (AUTONOMIE) which compare with proposed recreational boat named PHERB.

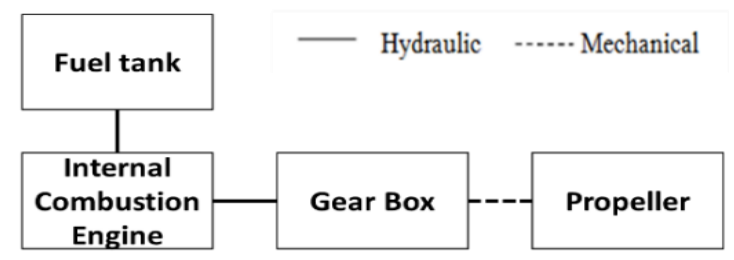

Figure 1. Block diagram of the CB powertrain

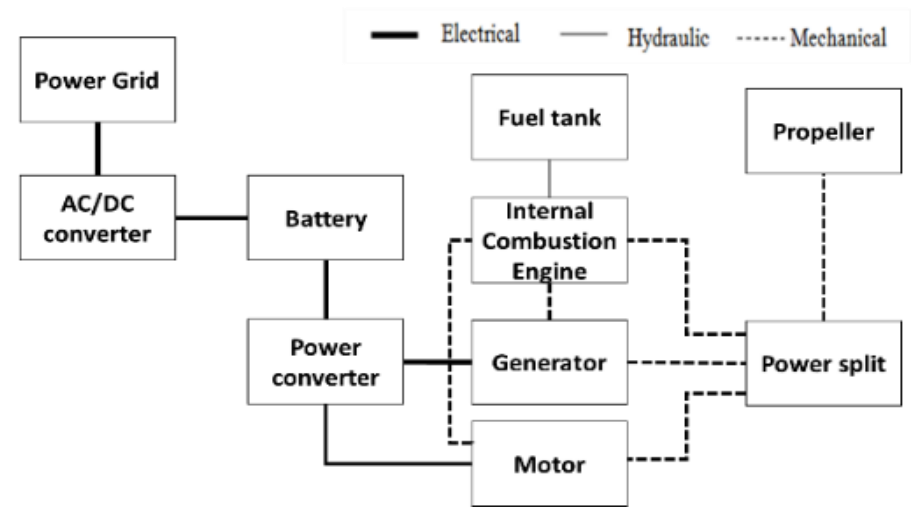

Figure 2. Block diagram of the PHEB powertrain

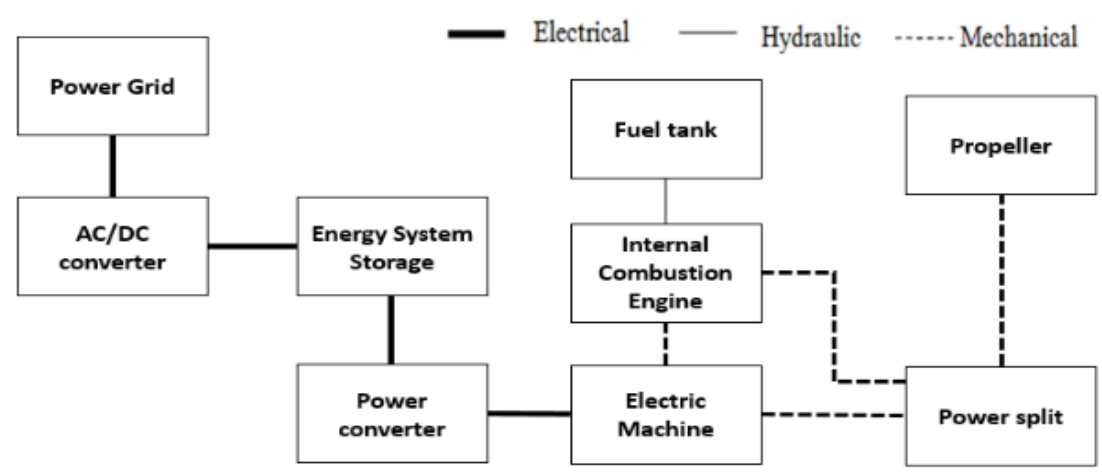

Figure 3. Block diagram of the proposed PHERB powertrain

\section{METHOD}

The method conducted in this research is divided by five phases which is model by software, PHERB vehicle model, and PHERB energy management system.

\subsection{ADVISOR and AUTONOMIE}

In this research, ADVISOR and AUTONOMIE shown in Figure 4 is the established software can be used as the reference to build the vehicle such as car, boat, bus, truck and so on. U.S. department of energy (DOE) and the national renewable energy laboratory (NREL) was developed ADVISOR as shown in Figure 
4 as a software based on the MATLAB/Simulink environment used to simulate and analyze conventional, electric, hybrid electric and plug-in hybrid electric vehicle [20]-[21]. AUTONOMIE was developed by argonne national laboratory (ANL) and sponsored by the DOE. The MATLAB/Simulink environment-based simulation toolbox supports rapid vehicle powertrain modeling and analysis of various powertrain and control systems through the evaluation of vehicle's fuel economy, performance, and energy efficiency under various dynamic or transient testing conditions [22]-[23]. The ADVISOR and AUTONOMIE models have been approved and utilized as a benchmark of reference display because ADVISOR and AUTONOMIE is the established software. To mimic the PHERB, the model has determined and tried by contrasting the reenactment results and ADVISOR and AUTONOMIE. Likewise, PHERB was produced as forward-looking vehicle simulation architecture comparable with AUTONOMIE show however ADVISOR uses in reverse looking vehicle simulation architecture.

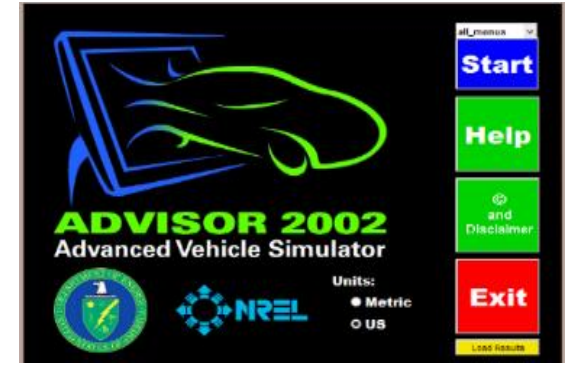

(a)

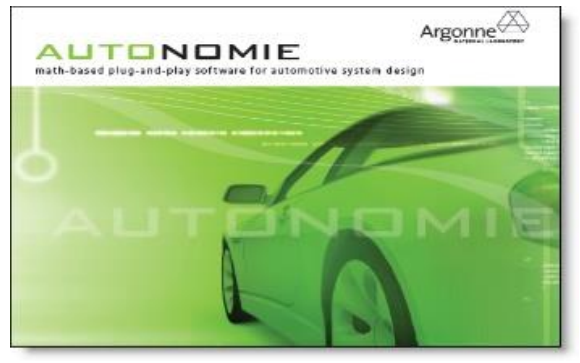

(b)

Figure 4. (a) ADVISOR and (b) AUTONOMI software

\subsection{PHERB vehicle model}

Design specifications, requirements, sizing and selection for EM, ICE and energy storage system (ESS) are carried out in order to identify the main components of PHERB powertrain. The EM, ICE and ESS are sized according to boat parameter, specifications, and performance requirements as shown in Table 1, based on the boat power requirement for steady state velocity using dynamic equation boat [24]-[28]. The boat type selected is a recreational boat. In simulation, the length of boat used is $12.4 \mathrm{~m}$ and density of water is $1000 \mathrm{kgm}-3$.

The enlargement of boat model starts with the estimations of boat energy and power needed for common driving situations based on the parameters and target specifications of the boat based on PHERB specification, parameter and requirement. Through a power flow analysis, the size and limit of each component are decided accordingly to get the necessities. Table 2 displayed the size and specifications used for PHERB [29]-[34].

Table 1. PHERB parameters, specifications and performance requirements

\begin{tabular}{llll}
\hline & \multicolumn{2}{c}{ Parameter and Specifications } \\
\hline Configuration & Series-Parallel & Configuration & Series-Parallel \\
Length overall, L & $12.4 \mathrm{~m}$ & Length between perpendicular, LP & $10.67 \mathrm{~m}$ \\
Length at waterline, LWT & $11.0 \mathrm{~m}$ & Density of water, $\rho$ & $1000 \mathrm{kgm}^{-3}$ \\
Breath, B & $1.8 \mathrm{~m}$ & Total propulsive efficiencies, $\eta \mathrm{T}$ & 0.9 \\
Draught, T & $0.64 \mathrm{~m}$ & & \\
& & Performance Requirement & \\
Maximum speed & Over $30 \mathrm{~km} / \mathrm{h}$ \\
EV range & $10 \mathrm{~km}$ & \\
\hline
\end{tabular}

Table 2. PHERB component specification

\begin{tabular}{cc}
\hline Component & Specifications \\
\hline ICE & $20 \mathrm{~kW} \mathrm{@} \mathrm{3000} \mathrm{rpm}$ \\
EM & $30 \mathrm{~kW} \mathrm{AC} \mathrm{induction} \mathrm{motor}$ \\
Battery & $\mathrm{Li}, 5 \mathrm{kWh}, 6 \mathrm{Ah}$ \\
\hline
\end{tabular}


All parts in PHERB obtain a mathematical model is combined. The boat performance is simulated in the MATLAB/Simulink environment with a special EMS and different driving cycle. Overall structure of PHERB model is illustrated in Figure 5.

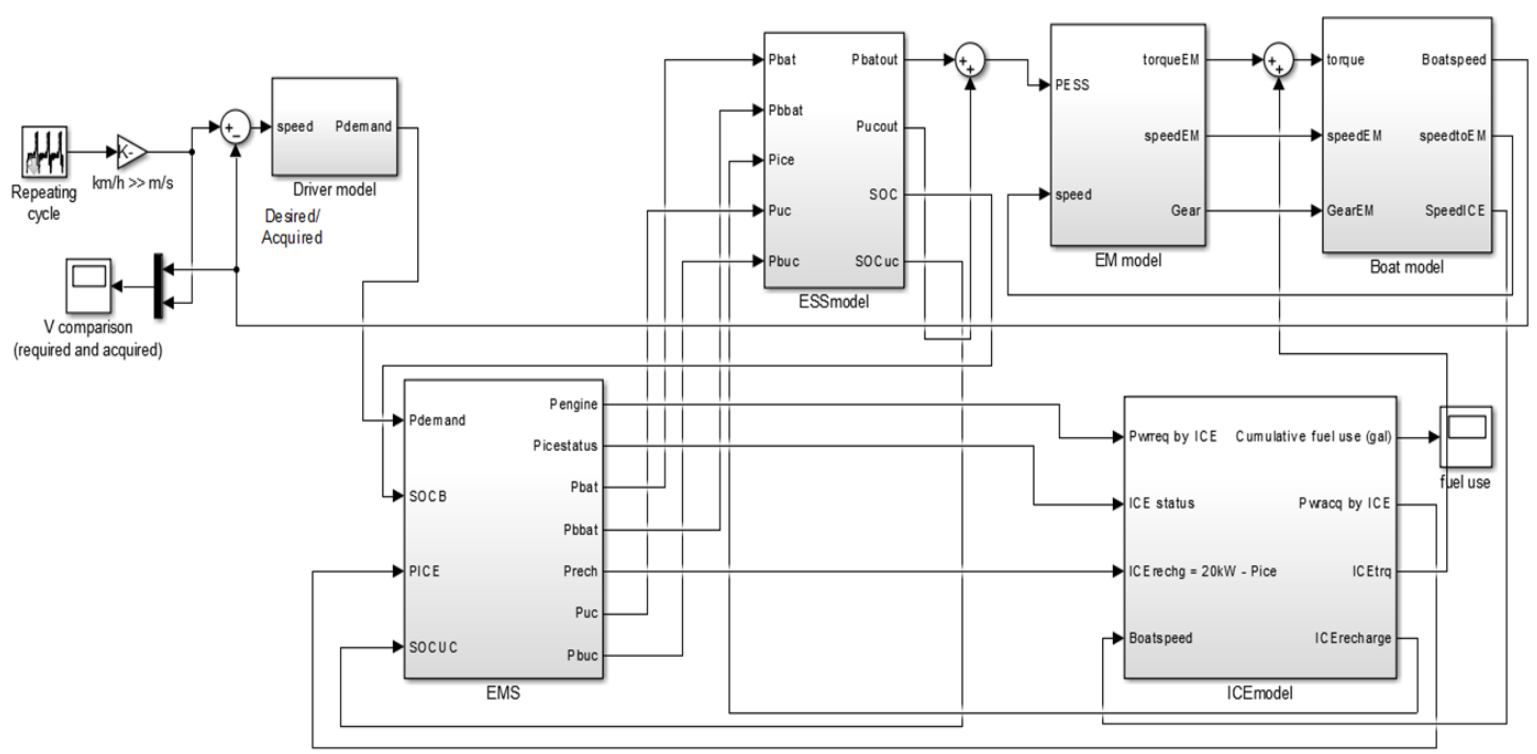

Figure 5. Overall structure of the PHERB model in MATLAB/Simulink

\subsection{PHERB energy management strategy}

EMS is dependable of choosing in which mode that the boat is working. A few working methods of the proposed EMS appeared in Figure 6 to control the flow of power among the ESS, EM, and ICE, including the mechanical braking, regenerative braking, motor only, engine recharge, motor and engine, and engine only mode refer to the boat demand in forward and reverse cruising and SOC level of ESS [35], [36].

The mechanical braking mode is started if the SOC of both ESS and the throttle position is high. Amid the regenerative braking mode, the distribution of absorbed regenerative power be determined by on the percentage of throttle position as well as on the SOC level of both storage units. EM only mode can be activated when the SOC level is high. When the ESS SOC and the speed are low, the ICE will drive the boat for charging the ESS. If the boat is cruising and the ESS has a moderate SOC, then the boat can be either ICE recharge or EM only mode refer to previous mode. If the boat acceleration is high, then the ICE will not have an opportunity to charge the ESS because the ICE only mode is activated.

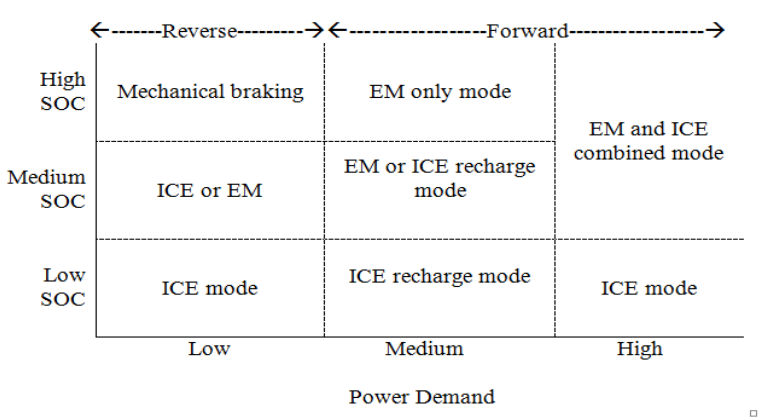

Figure 6. PHERB EMS modes of operation

\section{RESULT AND DISCUSSION}

This section is divided to two phases which is PHERB model verification and PHERB fuel economy and emission analysis. 


\subsection{PHERB model verification}

For model verification, PHERB model is modified to incorporate the plug-in hybrid electric vehicle (PHEV) model and EMS. The PHERB model is verified using ADVISOR model and AUTONOMIE model.

\subsubsection{Drive cycles}

Two standard U.S. environmental protection agency (EPA) drive cycles: the highway fuel economy test (HWFET) and urban dynamometer driving schedule (UDDS) are simulated to verify the model of PHERB as plug-in hybrid vehicle. Figure 7 and Figure 8 illustrated the HWFET and UDDS drive cycles which is finishes at 765 seconds and 1369 seconds, respectively.

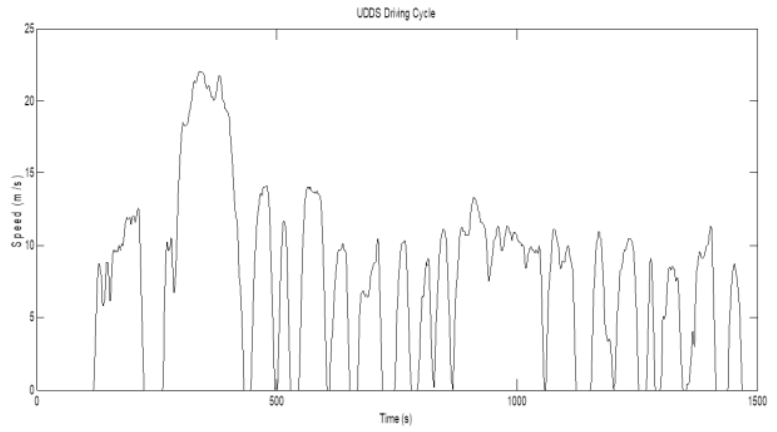

Figure 7. UDDS driving cycle

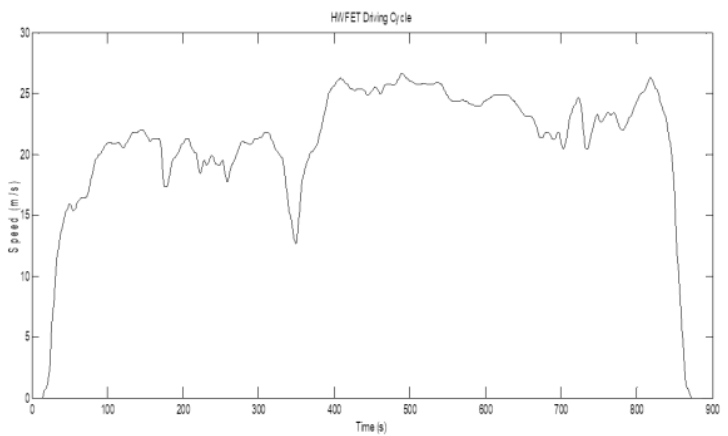

Figure 8. HWFET driving cycle

\subsubsection{Boat performance}

Figures 9-12 outlined the simulation regarding the boat speed and force via ADVISOR and AUTONOMIE. As appeared in Figures 9-12, the real boat force and speed of the HWFET and UDDS drive cycles reproduced by the ADVISOR or AUTONOMIE (blue lines) and the PHERB show (red lines) concur well with each other.

\subsubsection{Energy system storage}

From the ESS output power, voltage and current in Figures 9-12, can assume that to attain speed boat during that period, the high-power demand is due to the highest current. The regenerative braking happens when the negative value on the graph display in the cycle. For ESS voltage, when ESS recharging in the regenerative braking mode, the voltage increases and decreases when the power needed from EM is high during current peak discharge. While the two-model configuration during HWFET and the UDDS drive cycles for SOC of the battery are represented in Figures 9-12.

The whole pattern of two models and energy depletion equals sensibly well. Nevertheless, there is some difference with the battery SOC aftereffects of the PHERB demonstrate and ordinary PHEV show in the UDDS and HWFET drive cycle utilizing ADVISOR and AUTONOMIE. This is because the PHERB model has a detention more regenerative braking energy and a better EMS.

\subsubsection{Electric machine}

The result of ADVISOR, AUTONOMIE and PHERB in term power, speed and torque used EM using the HWFET and UDDS drive cycles are included in Figures 9-12. So that, when the boat accelerates, the required EM torque increments rapidly, and when the boat achieves the moderately stable interstate speed level, a smaller torque is required to beat the resistance and air drag to the boat. The speed, torque and power results from the two model compare sensibly fit.

\subsubsection{Propeller}

Figures 11 and 12 delineates the wheel torque and speed necessity for the HWFET drive cycle of the two models $600 \mathrm{Nm}$ happens when the boat is accelerating from stop to the acceleration. The needed torque at that point lessens since the HWFET drive cycle just comprises of gentle increasing velocities and decelerations. The general outcomes and patterns coordinate intently. Figures 9 and 10 demonstrates the haggle required amid the UDDS drive cycle and the outcomes from ADVISOR, AUTONOMIE and PHERB show coordinate exceptionally well. 


\subsubsection{Acquired and required speed}

Figures 9-12 show that the acquired and required speed concur sensibly well. The PHERB model followed the desired drive cycle speed very well for both standard drive cycles match with ADVISOR and AUTONOMIE.

In combination with the previous discussion, it can be concluded that the results of the components of the vehicle subsystems of PHERB model are correctly sized as the boat is capable of achieving performance to a target velocity.
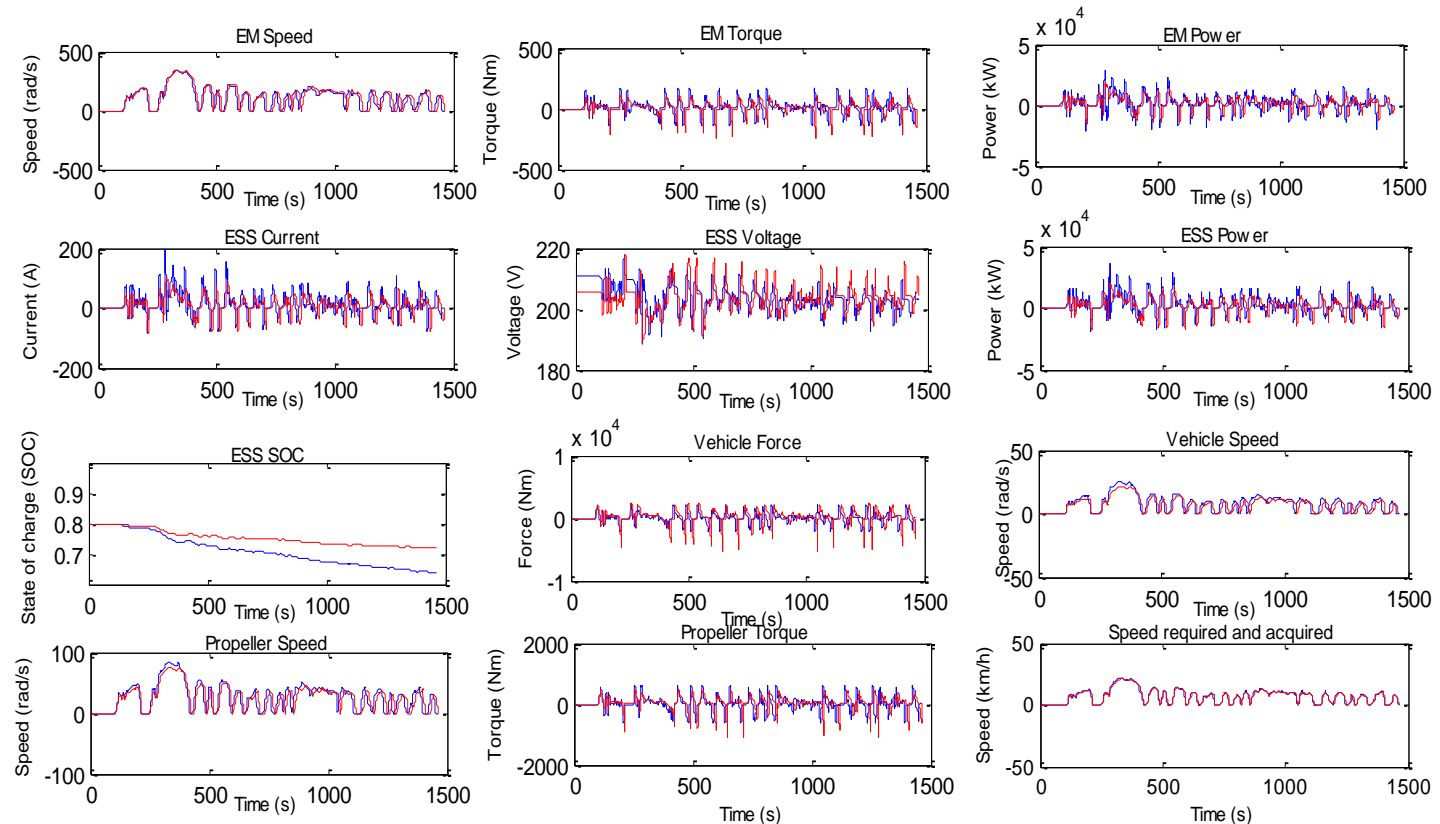

Figure 9. Simulation results of UDDS driving cycle using AUTONOMIE (Blue: ADVISOR, Red: PHERB)
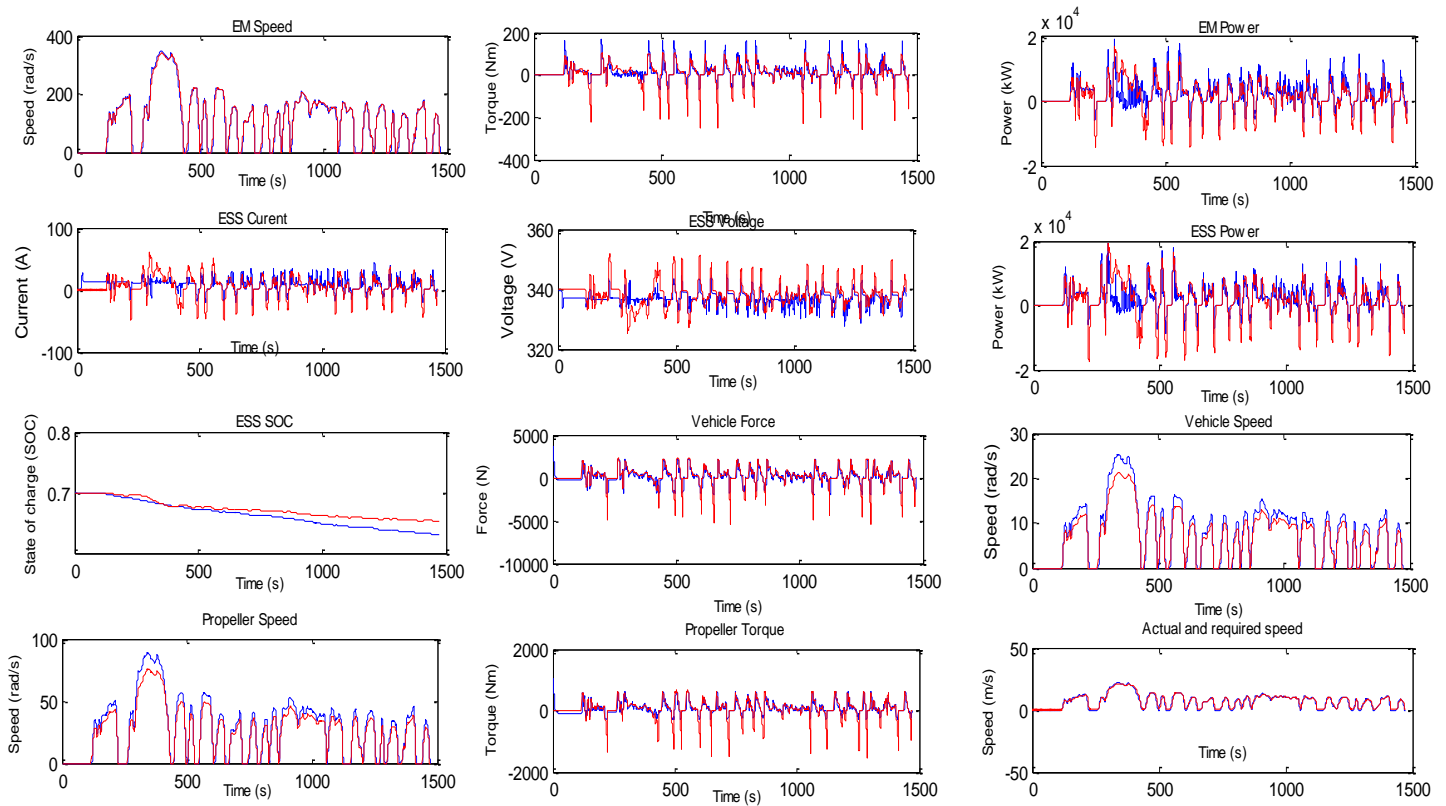

Figure 10. Simulation results of UDDS driving cycle using ADVISOR (Blue: ADVISOR, Red: PHERB) 

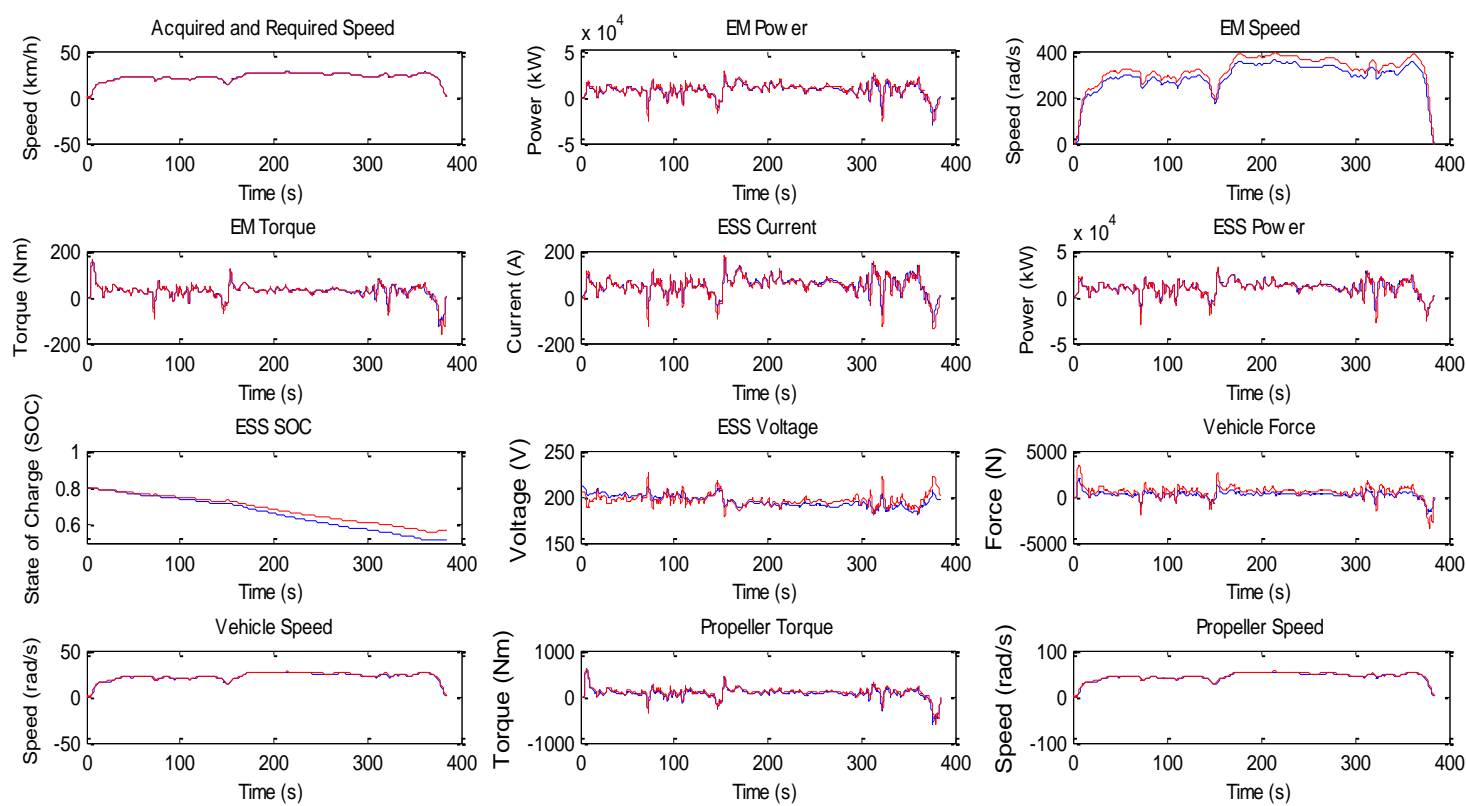

Figure 11. Simulation results of HWFET driving cycle using AUTONOMIE (Blue: ADVISOR, Red: PHERB)
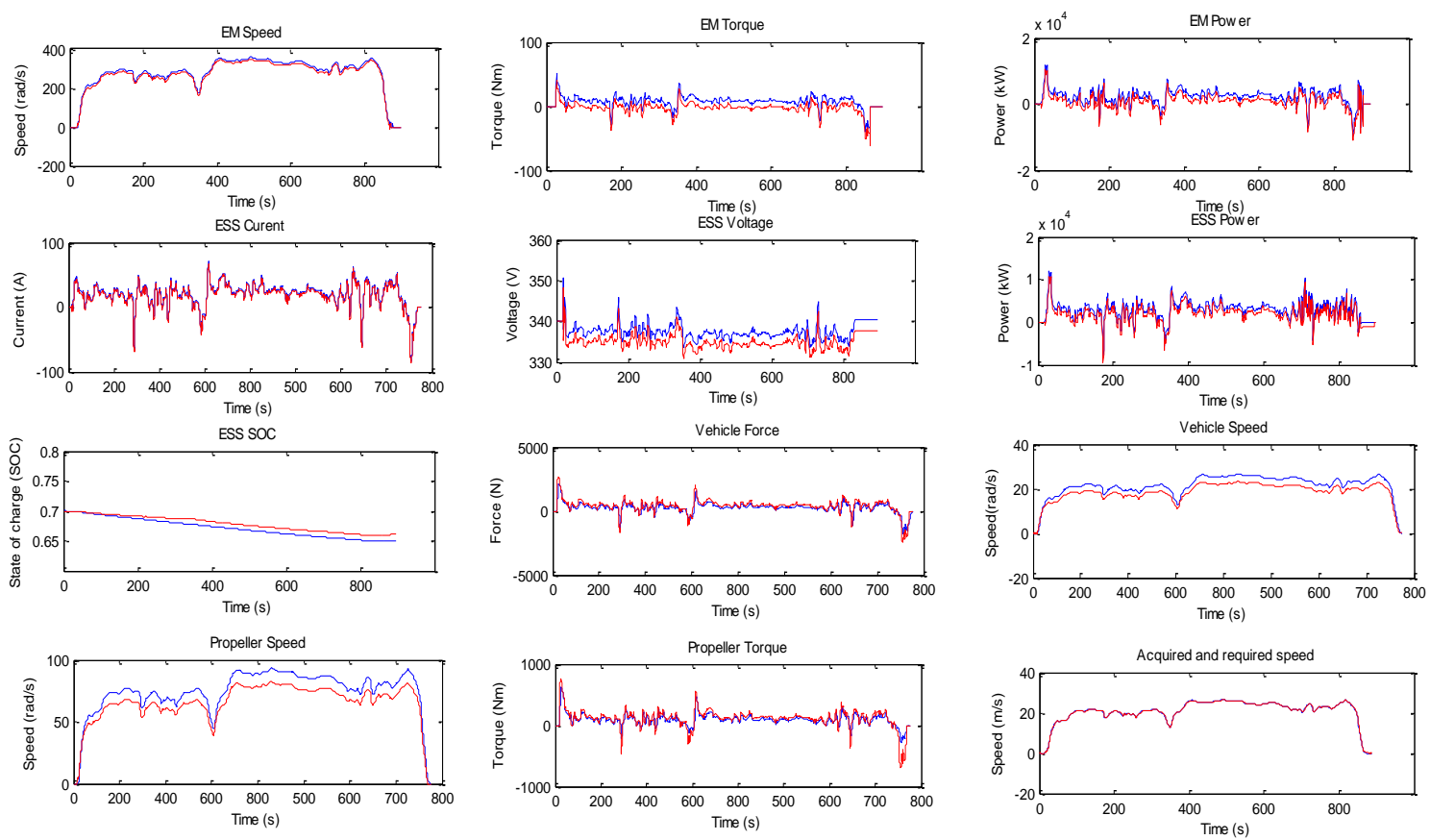

Figure 12. Simulation results of HWFET driving cycle using ADVISOR (Blue: ADVISOR, Red: PHERB)

\subsection{Pherb fuel economy and emission analysis}

This analysis compared the fuel economy (FE) and emissions shown in Tables 2-3 which is hydrocarbon $(\mathrm{HC})$, carbon-monoxide $(\mathrm{CO})$, nitrogen-dioxide $(\mathrm{NOx})$ and carbon dioxide $\left(\mathrm{CO}_{2}\right)$ using PHERB, ADVISOR and AUTONOMIE, for the HWFET driving cycle, UDDS driving cycle and a few water drive cycles. The water driving cycle used are Kuala Terengganu (KT), Seberang Takir (ST), Kampung Laut (KL), Tasik Kenyir (TK), and Pulau Kapas (PK) presented in Figure 13. The FE and FE improvement can be determined using (1) and (2) (37-39) where D is distance in miles and $\mathrm{V}_{\text {fuel }}$ is volume of fuel in consumed in gallons. 
$F E(m p g)=\frac{D}{V f u e l}$

Percentage of FE improvement $=\frac{\text { Before }- \text { After }}{\text { Before }} \times 100 \%$

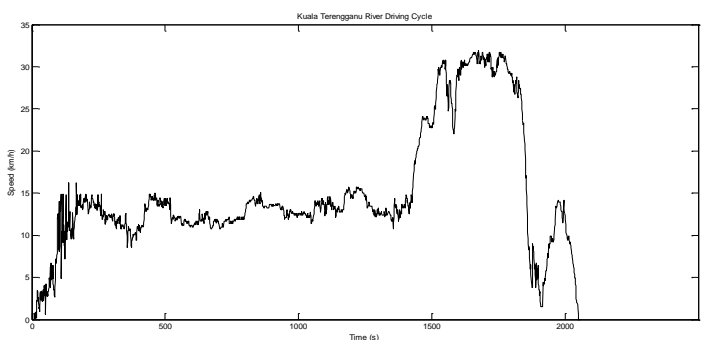

(a)

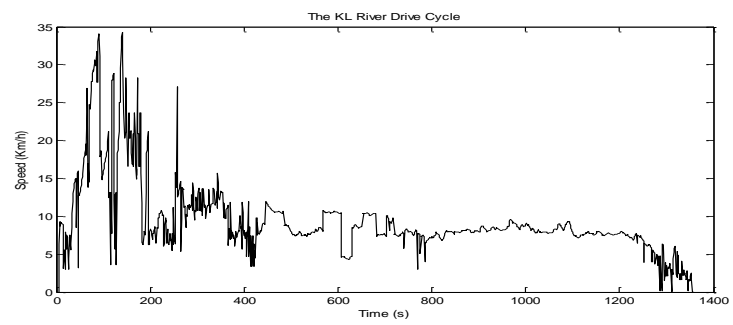

(c)

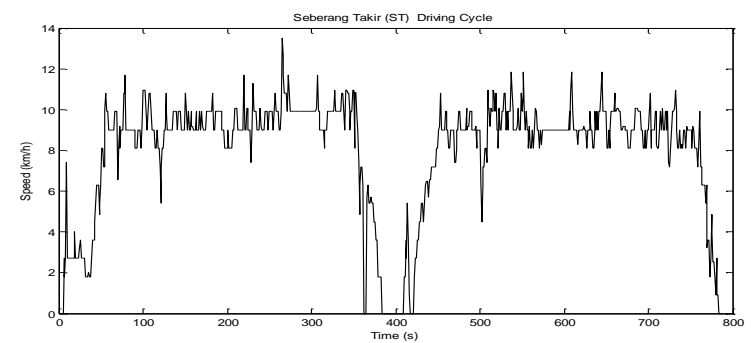

(b)

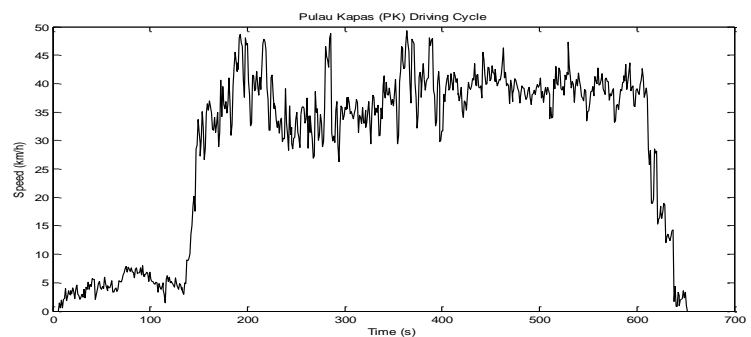

(d)

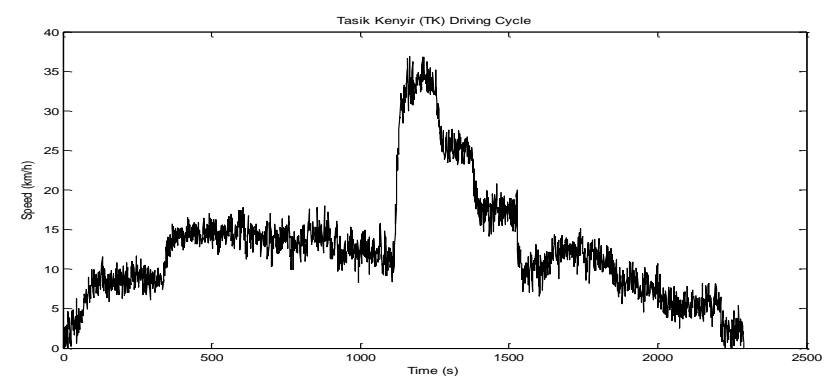

(e)

Figure 13. Water driving cycle used, (a) KT driving cycle, (b) ST driving cycle, (c) KL driving cycle, (d) PK driving cycle, (e) TK driving cycle

The different pattern of driving cycle and models were given the different value of FE and emission. The FE and emission of PHERB, ADVISOR and AUTONOMI model are listed in Tables 2-3 is analysed using model analysis in MATLAB/Simulink environment.

From the Tables 2-3, a significant improvement in the fuel economy and emissions were achieved by the PHERB model. Based on the analysis results, the following observations can be made. The FE of the PHERB is about $33 \%$ higher than that of the ADVISOR model, $13 \%$ higher than the AUTONOMIE model for the KT drive cycle. For ST driving cycle, the FE of PHERB is $36 \%$ higher than that of the ADVISOR model and $15 \%$ higher than the AUTONOMIE model. Hence, for KL, TK and PK driving cycles show the increasing in FE of PHERB such as 42\%, 77\%, and 20\% than ADVISOR model and 14\%, 18\%, 11\% higher compared to AUTONOMIE model. Besides that, the FE of the PHERB for UDDS and HWFET driving cycle presented $17 \%$ and $10 \%$ for ADVISOR model, while for AUTONOMIE model, PHERB was improved about $8 \%$ and $7 \%$ respectively. 
In emission studied, PHERB and ADVISOR model show the result of three type emission such as HC, CO, and NOx. The results displayed PHERB model has a lower emission compared to ADVISOR model. It differences for AUTONOMIE, AUTONOMIE model only given the result for CO2 emission. This happens because ESS model in PHERB model have battery and UC bank but in ADVISOR and AUTONOMIE model has only the battery in the ESS. UC be the important role to improve the FE and emissions. Besides that, a special EMS is used in PHERB model that can increase the FE and reduced the emission.

Table 2. Fuel economy and emission using ADVISOR and AUTONOMIE

\begin{tabular}{|c|c|c|c|c|c|c|c|c|c|c|}
\hline \multirow{3}{*}{ Driving Cycle } & \multicolumn{5}{|c|}{ ADVISOR } & \multicolumn{5}{|c|}{ AUTONOMIE } \\
\hline & \multirow{2}{*}{$\begin{array}{l}\text { Fuel Economy } \\
\text { (mpg) }\end{array}$} & \multicolumn{3}{|c|}{ Emission $(\mathrm{g} / \mathrm{m})$} & \multirow[b]{2}{*}{$\mathrm{CO}_{2}$} & \multirow{2}{*}{$\begin{array}{l}\text { Fuel Economy } \\
\text { (mpg) }\end{array}$} & \multicolumn{4}{|c|}{ Emission (g/m) } \\
\hline & & $\mathrm{HC}$ & $\mathrm{CO}$ & NOx & & & $\mathrm{HC}$ & $\mathrm{CO}$ & NOx & $\mathrm{CO}_{2}$ \\
\hline KT & 73.5 & 0.462 & 0.492 & 0.107 & - & 95.5 & - & - & - & 42.171 \\
\hline ST & 43.0 & 1.757 & 1.734 & 0.121 & - & 56.8 & - & - & - & 21.097 \\
\hline KL & 41.9 & 1.018 & 1.319 & 0.340 & - & 62.5 & - & - & - & 46.080 \\
\hline TK & 40.7 & 0.565 & 0.587 & 0.175 & - & 145.5 & - & - & - & 112.045 \\
\hline PK & 35.0 & 0.684 & 0.859 & 0.274 & - & 38.8 & - & - & - & 155.416 \\
\hline UDDS & 62.3 & 0.561 & 0.743 & 0.195 & - & 68.9 & - & - & - & 18.980 \\
\hline HWFET & 87.6 & 0.394 & 0.602 & 0.183 & - & 90.4 & - & - & - & 22.910 \\
\hline
\end{tabular}

Table 3. Fuel economy and emission using PHERB

\begin{tabular}{cccccc}
\hline \multirow{2}{*}{ Driving Cycle } & \multicolumn{4}{c}{ PHERB } & \multicolumn{2}{c}{ Emission $(\mathrm{g} / \mathrm{m})$} & \\
& Fuel Economy $(\mathrm{mpg})$ & $\mathrm{HC}$ & $\mathrm{CO}$ & $\mathrm{NOx}$ & $\mathrm{CO}_{2}$ \\
\hline KT & 109.8 & 0.547 & 0.279 & 0.000 & - \\
ST & 66.7 & 1.046 & 0.534 & 0.000 & - \\
KL & 72.6 & 0.878 & 0.448 & 0.000 & - \\
TK & 178.0 & 0.711 & 0.474 & 0.057 & - \\
PK & 43.7 & 0.296 & 0.151 & 0.000 & - \\
UDDS & 74.7 & 0.415 & 0.215 & 0.000 & - \\
HWFET & 97.3 & 0.224 & 0.203 & 0.047 & - \\
\hline
\end{tabular}

\section{CONCLUSION}

The boat subsystems in terms of ESS current, voltage, output power and SOC, EM speed and torque, boat speed and force and propeller speed and torque are within reasonable and expected range of actual typical behavior of these subsystems. The components of the boat subsystems are correctly sized as the vehicle can achieve performance to a target velocity. The fuel economy and emissions for the driving cycle used shown similarity based on software used because ADVISOR and AUTONOMIE have different characteristic and focused on different part in modelling and simulation. It can be concluded that results of the PHERB model are the most precise compared to ADVISOR and AUTONOMIE. So that, it can be used as reference to build the prototype of hybrid electric recreational boat in Malaysia environment.

\section{ACKNOWLEDGEMENTS}

The authors would like to be obliged to Universiti Malaysia Terengganu (UMT) for UMT Scholarship, Ministry of Education Malaysia for providing financial assistance under FRGS (59353) grant and Faculty of Ocean Engineering Technology and Informatics, UMT for all their technical and research support for this work to be successfully complete.

\section{REFERENCES}

[1] Powell B. K, Bailey K. E, and Cikane S. R, "Dynamic Modeling and Control of Hybrid Electric Vehicle Powertrain Systems," IEEE Control Systems, pp. 0272-1708, 1999, DOI: 10.1016/S1474-6670(17)39137-1.

[2] Karen LB, Mehrdad E and Preyas K, "A Matlab-Based Modeling and Simulation Package for Electric and Hybrid Electric Vehicle Design," IEEE Transactions on Vehicular Technology, vol. 48, no. 6, pp. 1770-1778, 1999, DOI: 10.1109/25.806769.

[3] Minami S, Toki T, Yoshikawa N, Hanada T, Ashida M, Kitada S, and Tsukuda K. A, "Newly Developed Plug-in Hybrid Electric Boat (PHEB)," Journal of Asian Electric Vehicles, 8, pp. 1385-1392, 2010, DOI: 10.4130/jaev.8.1385.

[4] Minami S, "A practical theory of the performance of low velocity boat," Journal of Asian Electric Vehicles, vol. 2, no. 1, pp. 535-539, 2004, DOI: 10.4130/jaev.2.535. 
[5] Minami S, Toki T, Yoshikawa N, Hanada T, Ashida M, Kitada S, and Tsukuda K. A, "Experimental performance of a model river cruising electric boat electric-powered by a fuel cell," Journal of Asian Electric Vehicles, vol. 1, no. 2, pp. 475-477, 2003.

[6] Minami S, "Designing the river cruise electric boat," Journal of Asian Electric Vehicles, vol. 1, no. 1, pp. 131-138, 2003.

[7] Minami S, Toki T, Yoshikawa N, Hanada T, Ashida M, Kitada S, and Tsukuda K. A, "On the performance of a newly developed plug-in hybrid boat (PHEB), Journal of Asian Electric Vehicles, vol. 11, no. 2, pp. 1653-1657, 2013.

[8] Minami S, "Performance of a newly developed plug in hybrid boat," Proceedings of EVS27. 2013.

[9] Eshani M, Gao Y, Gay SE, Emadi A, "Modern electric, hybrid electric and fuel cell vehicles," CRC Press, New York 2005.

[10] D. W. Gao, C. Mi and A. Emadi, "Modeling and Simulation of Electric and Hybrid Vehicles," in Proceedings of the IEEE, vol. 95, no. 4, pp. 729-745, April 2007, doi: 10.1109/JPROC.2006.890127.

[11] Chan CC, Bouscayrol A, Chen K, "Electric, Hybrid and Fuel Cell Vehicles: Architectures and Modeling," IEEE transactions on Vehicular Technology, vol. 59, no. 2, pp. 589-598, 2010, DOI: 10.1109/TVT.2009.2033605.

[12] Rufer A, Hotellier D, Barrade P, "A supercapacitor based energy-storage storage substation for voltage compensation in weak transportation networks," IEEE transaction on Power Delivery, vol. 19, no. 2, pp. 629-636, 2004, DOI: 10.1109/TPWRD.2004.824408.

[13] Horrein L, Bouscayrol A, Delarue P, Verhille JN, Mayet C, "Forward and Backward simulations of a power propulsion system," IFAC Proceedings Volumes, vol. 45, no. 21, pp. 441-446, 2012, DOI: 10.3182/20120902-4FR-2032.00078.

[14] Cikanek S. R, Bailey K. E, and Powell B. K, "Parallel Hybrid Electric Vehicle Dynamic Model and Powertrain Control," Proceedings of the American Control Conference, Albuquerque, New Mexico. 1997, DOI: 10.1109/ACC.1997.611888.

[15] Ghorbani R, Bibeau E, Zanetel P and Karlis A, "Modeling and Simulation of a Series Parallel Hybrid Electric Vehicle Using REVS, 2007 American Control Conference, New York, NY. 2007; pp. 4413-4418, DOI: 10.1109/ACC.2007.4282828.

[16] Ippoliot L, Loia V and Siano P, "Extended Fuzzy C-Means and Genetic Algorithms to Optimize Power Flow Management in Hybrid Electric Vehicles," Fuzzy Optimization and Decision Making, vol. 2, pp. 359-374, 2003, DOI: 10.1023/B:FODM.0000003954.49357.b3.

[17] Won J-S, Langari R, and Ehsan M, "An Energy Management and Charge Sustaining Strategy for a Parallel Hybrid Vehicle with CVT," IEEE Transactions on control system technology, vol. 13, no. 2, 2005, DOI: 10.1109/TCST.2004.838569.

[18] Hermance D, and Sasaki S, "Hybrid electric vehicles take the streets," IEEE Spectrum, p. 4852, 1998, DOI: $10.1109 / 6.730520$.

[19] Bulter KL, Ehsani M and Kamath P, "A Matlab-based modeling and simulation package for electric and hybrid electric vehicle design," IEEE Transaction of Vehicular Technology, pp. 48-56, 1999, DOI: 10.1109/25.806769.

[20] Wipke B. K, "ADVISOR 2.1: A User-friendly Advanced Powertrain Simulation using a Combined Backward/forward Approach," IEEE Transactions on Vehicular Technology, vol. 48, pp. 1751-1761, 1999, DOI: 10.1109/25.806767.

[21] Markel T, Brooker A, Hendricks T, Johnson V, Kelly K, Kramer B, Keefe, S. Sprik MO', and Wipke K, "ADVISOR: a Systems Analysis Tool for Advanced Vehicle Modeling," ELSEVIER Journal of Power Sources, vol. 110, pp. 255-266, 2002, DOI: 10.1016/S0378-7753(02)00189-1.

[22] Onoda S and Emadi A, "PSIM-based modeling of automotive power systems: Conventional, electric, and hybrid electric Vehicles," IEEE Trans. Vehicle Technology, vol. 53, no. 2, pp. 390-400, 2004, DOI: 10.1109/TVT.2004.823500.

[23] Rui Cheng, "Modeling and Simulation of Plug-in Hybrid Electric Powertrain System for Different Vehicular Applications," Thesis. University of Victoria, Australia. 2016, DOI: 10.1109/VPPC.2015.7352976.

[24] Freire T, Sousa DM, and Branco PJC, "Aspects of modeling an electric boat propulsion system," Computational Technologies in Electrical and Electronics Engineering (SIBIRCON), 2010 IEEE Region 8 International Conference on, IEEE, 2010, DOI: 10.1109/SIBIRCON.2010.5555086.

[25] Corredor L, Baracaldo L, Jaramillo L, Gutiérrez J, and Jiménez D, “A comprehensive energy analysis of a hybrid motorization for small/medium boats," International Conference on Renewable Energies and Power Quality, pp. 28-30 March, Santiago de Compostela, Spain, pp. 1-6. 2012, DOI: 10.24084/repqj10.789.

[26] Luttenberger L. R. A. I, Šestan A, and Vladimir N, "Integrated power systems in small passenger ships," Plug Boat, World Electric \& Hybrid Boat Summit. 2013.

[27] Nóbrega J, Dan T, and Rubanenco I, "Electric Propulsion Applied for Research Vessel," International Conference on Renewable Energies and Power Quality; 20-22 March; Bilbao, Spain, pp. 1-6, 2013, DOI: $10.24084 /$ repqj11.240.

[28] Norbakyah J. S, Atiq W. H, and Salisa A. R, “Components Sizing for PHERB Powertrain using ST River Driving Cycle," 2015 IEEE International Conference on Computer, Communication, and Control Technology (I4CT 2015) Kuching, Sarawak, Malaysia. 2015, DOI: 10.1109/I4CT.2015.7219613.

[29] Norbakyah J. S, Atiq W. H, and Salisa A. R, "Impact Component Sizing on PHERB Powertrain using Tasik Kenyir Driving Cycle,” Australian Journal of Basic and Applied Sciences, vol. 9, no. 25, pp. 56-59, 2015. 
[30] Norbakyah J. S, Atiq W. H, and Salisa A. R, "Power requirements for PHERB powertrain," IOP Conf. Series: Materials Science and Engineering 100. 2015,

[31] Norbakyah J. S, Atiq W. H, and Salisa A. R, "Powertrain Main Components Sizing Of PHERB Using KL River Driving Cycle," ARPN Journal of Engineering and Applied Sciences, vol. 10, no. 18, pp. 8507-8510, 2015.

[32] Norbakyah J. S and Atiq W. H, "A Conceptual Design of Main Components Sizing for PHERB Powertrain," Jurnal Teknologi, vol. 76, no. 8, pp. 107-111, 2015, DOI: 10.11113/jt.v76.5633.

[33] Norbakyah J. S, Shahrizan A. N, Atiq W. H, "Muhamad Zalani and Salisa AR. Modelling, Simulation and Optimization of Discharge Ultracapacitor for Plug in Hybrid Electric Recreational Boat," ARPN Journal of Engineering and Applied Sciences, vol. 12, no. 6, pp. 1932- 1937, 2017.

[34] Abdul Rahman S, Walker P. D, Zhang N, Zhu J. G, and Du H, "A Comparative Study of Vehicle Drive Performance and Energy Efficiency," Sustainable Automotive Technologies, pp. 319-324, 2012, DOI: 10.1007/978-3-642-24145-1_42.

[35] Abdul Rahman S, Zhang N, and Zhu. J. G, "Genetic Algorithm for UTS Plug-in Hybrid Electric Vehicle Parameter Optimization Abdul Rahman," 13th Asia Pacific Vibration Conference. 2009.

[36] Gonder J and Simpson A, "Measuring and Reporting Fuel Economy of Plug-In Hybrid Electric Vehicles," WEVA Journal, vol. 1, pp. 1-8, 2007, DOI: 10.3390/wevj1010134.

[37] Abdul Rahman S, Zhang N, and Zhu J. G, "A Comparison on Fuel Economy and Emissions for Conventional Hybrid Electric Vehicles and the UTS Plug-in Hybrid Electric Vehicle," 2010 The 2nd International Conference on Computer and Automation Engineering (ICCAE), vol. 60, pp. 44-54, 2011, DOI: 10.1109/ICCAE.2010.5451533.

[38] Kim N, Rousseau A, and Rask E, "Autonomie model validation with test data for 2010 Toyota Prius," Argonne National Laboratory. SAE International, pp. 1-14, 2012, DOI: 10.4271/2012-01-1040.

[39] Yaich M, Ghariani M, and Hachicha M. R, "Modeling and Simulation of Electric and Hybrid Vehicles for Recreational Vehicle," 16th international conference on Sciences and Techniques of Automatic control \& computer engineering, pp. 181-187, 2015, DOI: 10.1109/STA.2015.7505098.

\section{BIOGRAPHIES OF AUTHORS}

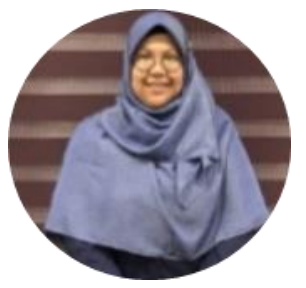

J. S. Norbakyah received the Bachelor of Applied Science (Physics Electronic and Instrumentation) and MSc and PhD from Universiti Malaysia Terengganu, Terengganu, in 2009, 2014 and 2019 respectively. She currently working as a lecturer at Univerisiti Malaysia Terengganu, Malaysia. Her main research interest is Electric Vehicle, Hybrid Electric Vehicle, Plug in Hybrid Vehicle, Modelling and simulation and renewable energy.

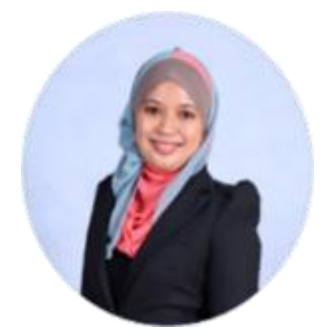

A. R. Salisa received the B.E. and M.E. in Electrical \& Electronics Engineering from University of Technology Petronas, Perak, Malaysia in 2004 and 2006, respectively while Ph.D. in Optimal Energy Management Strategy for the University of Technology Sydney Plug-In Hybrid Electric Vehicles from University of Technology Sydney (UTS), Australia. She is currently working as a senior lecturer at University Malaysia Terengganu, Malaysia. Her research interests are in Hybrid Electric Vehicles, innovation powertrain, simulation and modeling, energy management strategy, driving cycles, fuel economy, emissions and optimization. 